産業・経済変革期の職場のストレス対策の進め方

各論 1 . 一次予防（健康障害の発生の予防）

教育，研修一リスナー教育一

三島徳雄 $^{1}$, 久保田進也 ${ }^{2}$

産業医科大学 ${ }^{1}$ 産業生態科学研究所精神保健学教室, ${ }^{2}$ 産業医実務研修センター

抄録 : 産業・経済変革期の職場のストレス対策の進め方

各論 1. 一次予防（健康障害の発生の予防）: 教育, 研 修一リスナー教育一：三島徳雄ほか。産業医科大学産業 生態科学研究所精神保健学教室一産業医学では, リスナ 一教育は一次予防として行われるのが普通である。ここ では積極的傾聴法を中心とする研修という点から, リス ナー教育の現状について報告した。傾聴は, Rogersの 3 条件（共感，無条件の肯定的関心，自己一致）に基づく 人間尊重の態度をもって相手の話を聴くことを意味す る.このような研修の必要性は幅広く解説されているが, 学術的な研究論文はそしい。このレビューでは, これま でに報告されてきたリスナー教育に関する報告につい て, 一貫して 3 条件に基づいて行われる狭義のリスナー 教育と, Rogers の理論とは異なる技法を組み合わせた 広義のリスナー教育に分けて検討した。前者の例として は, 池見らによる人間尊重の態度の重要性に関する研究 があり, 久保田ら，三島ら，および宮城は実際の研修に ついて報告している，後者の例としては, 森崎および浜 口らは，交流分析等を含む彼等の研修を報告している. 最後に，今後はリスナー教育の評価に関する研究が必要 であるだけでなく，人材育成の視点から傾聴を考える必 要があることも指摘した.

（産衛誌 2001; 43: 27-31）

キーワード : Listener education, Primary prevention,

2000 年 12 月 27 日受付; 2001 年 2 月 9 日受理

連絡先：三島德雄 $\bar{\top} 807-8555$ 北九州市八幡西区医生ヶ丘 $1-1$

产丵医科大学産業生態科学研究所精神保健学教室
Active listening, Rogers' three conditions, Person-centered attitude

\section{I 、はじめに}

このレビューで扱う内容は一次予防の中で教育, 研修 の一つとしてのリスナー教育である。これまでリスナー 教育, リスナー研修という表現が使われた場合でも，そ れを実施する者が意味するところは，必ずしも一致して いないように思われる，そこで，多少堅苦しい議論にな るが，まず，用語の面を整理しておきたいと思う.

リスナー教育の「リスナー」とは listener（聴き手) のことであり,リスナー教育という表現は「リスナーを 養成するための教育」ということになるであろう．listen という言葉自体に「注意して聞く」との意味が含ま れており，それに対応する日本語としては，「聞く」で はなく，「聴く」が用いられる、リスナー教育という場 合に，綮密に言えば，実際に用いられる研修方法につい ては何も規定していない. しかし，他のレビューのテー マやlistenerの意味から考えて, このレビューでは「積 極的傾聴法」を中心とする方法により実施される教育, 研修を扱うものと考える，そこで，まず，積極的傾聴法 について説明を加える.

積極的傾聴（以下，傾聴と略す）は active listening の訳であり, アメリカの心理学者である C.R. Rogers $(1902-1987)^{1)}$ が提唱した, 人間尊重の態度 (personcentered attitude, PCA $)^{2)}$ に基づく聴き方を意味する. Rogersは心理療法に抢ける治療者とクライエントの関 係を重要視し, 治療者の治療促進条件の研究に基づいて, 3つの条件が重要なものと考えるようになった，今日で は「Rogersの 3 条件」として心理療法やカウンセリン 
グの分野でよく知られている。皇の 3 条件とは，次のよ うなものである：

（1）治療者はクライエントに対して共感的理解を示すこ と.

かけ離れた視点ではなく，相手の立場になって相 手の内面から理解しょうとする態度を意味する.

(2) 治療者はクライエントに対して無条件の肯定的関心 を示すこと。

聞き手にとって好ましいクライエントの言動だけ をとりあげるのでなく，クライエント自身に対して 無条件に肯定的な関心を示すことを意味する。

（3）治療者自身が一致（自己一致）の状態にあること. 治療者自身に感じられる気持ちに対しても開かれ ていること，必要であれば，その感じを相手に表明 することが求められる.

このような態度で相手の話を聴くことは，単に心理療 法において重要であるだけでなく，建設的な人間関係を 築く上でも重要であると考えられるようになった。そこ で, 心理療法の専門家だけでなく，一般の人々が練習を 通じてこの態度を獲得し, 相手の話をじっくりと聴くこ とが出来るようになるための方法を意味する場合に，積 極的傾聴法（以下，傾聴法と略す）という言葉がよく用 いられる. 医学領域でも傾聴は重要な態度と考えられて 抒り，心身医学で強調される受容・共感とも通じる態度 であると考えられる。

産業医学で傾聴法が注目される場合，多くの場合は管 理監督者の教育に扔いてである。そのため，傾聴法によ る研修を，その対象と言う点から見た場合には，管理監 督者教育, 研修とほとんど重なってしまう。以下に示す 文献においても，管理監督者を対象とした報告が大部分 である。

\section{II. リスナー教育の現状}

\section{1. リスナー教育の種類}

Rogersの 3 条件に基づく傾聴法の練習の場合, 練習 者は徹底して相手の話を聴くことが期待されている。研 修では，研修参加者が「話し手」，「聴き手」，「オブザー バー」の役割をそれぞれとって練習する場合が多いが, この際，聴き手が傾聴の練習をすることになる．3条件 を重視した練習では，聴き手に対して，「話し手にアド バイスをするのではなく，話し手の考えていること，感 じていることを理解しようとして傾聴する」ように指導 されるのが普通である。

前述の無条件の肯定的関心は，言い換えれば「話し手 の話を，聴き手の価值観に基づいて評価することをしな い (nonjudgmental) で聴くこと」でもある。これは言 葉の上では簡単に説明できるが, 実際に参加者がそのよ うな態度を体得するのは簡単なことではない。従って,
これを徹底して行おうとすれば，指導者は研修そのもの が一貫して PCAに基づくものとなるように配虑する必 要がある。この場合には, 指導者が傾聴練習以外に, 説 明, 解釈, 指摘といった行動を伴う他の方法論に基づく 練習を組み合わせることは困難である。そこで，このよ うに Rogersの 3 条件で一貫して行われるリスナー教育 を，ここでは「狭義のリスナー教育」と表現することに する.

これに対して，参加者に対してPCAの学習だけでな く，Rogersの理論とは異なる理論に基づく研修，教育 がリスナー教育において実施されることもある。例えば， 交流分析の技法を研修に組み込み，交流分析に基づいて， 人間関係の理解の仕方を指導者が説明するような場合で ある。このような教育では，参加した管理監督者が，単 に部下の話を聴くだけでなく，部下の性格や行動パター ンを理解した上で適切な対応が出来るようになることが 目標となる。このように，交流分析やその他の理論に基 づいて部下の性格を評価する場合には，話し手の話を聴 き手の基準に基づいて評価しないという態度とは異なる 接し万を練習することになり，㛜密に言えばRogersの 3 条件からは外れることになる，そこで，このレビュー では，このようなリスナー教育を便宜上「広義のリスナ 一教育」と呼ぶことにする。

\section{2. 狭義のリスナー教育}

傾聴法が産業界で取り入られるようになったのは，

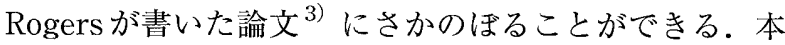
論文でRogers は企業の管理監督者の基本的任務として 「部下の職場適応に対する援助と指導」があり，部下の 能力を育成し, 責任と権限を与え，チームワークを作り 上げるために「ともに働く人たちの言うことを意識的に 注意深く聴く」という能力が大切であることを説いてい る.わが国では前述の諭文を社団法人日本産業訓練協会 が訳出しているが，本法をどのように管理者教育に用い たかについての文献はそしい.

近年わが国の産業界において傾聴法が注目されるよう になったのは，昭和 63 年に労㗢安全衛生法が一部改正 され労働者の健康保持增進に注目が集まったことが関係 していると考えられる．職場メンタルヘルスへの具体的 な取り組みとして (財)中央労働哭害防止協会 (中災防) が中心となってトータルヘルス・プロモーション・プラ ンを推進し，その活動の一貫として「心理相談員」「リ スナー教育」などが養成，実施されるようになった。そ のテキスト ${ }^{4)}$ では心理相談員の傾聴能力向上のために 「傾聴力を高める訓練法」が具体的に解説されている. 職場のメンタルヘルスに関する解説書等では，傾聴法な いしは関連技法の説明が行われることが多いため，この 種の文献は多数に上るものと思われるが，学術的な論文 
となると非常にそしいのが現状である5).

狭い意味での傾聴法の職域における活用に関するもの として重要な報告は, 池見らによる研究 ${ }^{6)}$ である. 池 見は複数の企業の従業員 1661 名に対し, その直属の上 司のPCA と従業員自身の疲労, うつ, 不安を評価させ て検討した。PCAが低い上司と高い上司の間では，疲 労, うつ, 不安に有意な差が認められ，いずれについて も上司の PCA が高いと認知した従業員が良好な結果を 示した．また，具体的な対応として某企業で傾聴法を中 心とした研修を行い，簡略版関係認知目録を用いて研修 における傾聴的態度の向上を報告している。

池見の研究のうち, PCA と疲労やうつ等との関係に 関する部分は横断的研究であり，因果的な解釈はできな い.しかし，あえてNIOSHの職業ストレスモデル 基づいて池見の研究を解积すれば，上司が部下に対し PCA で接することにより，人間関係由来の職場ストレ ッサーが軽減し，部下の度労，うつ，不安といったス卜 レス反応が低下する可能性を示したものと思われる.

Kubota ら ${ }^{8 ）}$ は傾聴法を中心とした研修を 60 名の管 理監督者に対して行い, 研修前後でアンケート調查を行 った結果，「人の話を真剣に聞く」「素直に聞く」などで， 受講者の傾聴的態度の向上が見られたことを報告してい る.また，別の 58 名の管理監督者集団に対しても久保 田 ${ }^{9 ）}$ は同様な研修を行い，参加者の精神健康度の変 化を検討し，研修後では参加者のうつ傾向が有意に低下 したと報告している.

三島ら ${ }^{10)}$ もPCAを重視する立場から指導した傾聴 法の研修について報告し, 指導上の注意点, 従来から行 われてきた指導の問題点，及び，効率よい指導を行うた めの工夫の必要性を指摘している。そのような具体的な 試みの一つとして，久保田ら ${ }^{11)}$ は発見的体験学習法を 提案している。これは，参加者がまだ気づいてはいない が，元来ある程度持っていると考えられる傾聴能力を， 自分の力で発見するように工夫した研修のやり方であ る。

宮城 ${ }^{12 ）}$ は，組織において個人の能力を引き出すため には，管理者は部下のキャリア開発，目標達成への動機 づけ，メンタルマネジメントなどの面において，上司と して部下の相談にのり，適切な助言，指導を行う必要が あると考えた，そのために管理者にはカウンセリング ・ マインドが求められると考え，PCAに基づくカウンセ リング教育を管理職に対して行った。その結果，共感や 傾聴など，コミュニケーション・スタイルにポジティブ な変化が見られたと報告している.

3. 広義のリスナー教育

森崎 ${ }^{13)}$ は管理監督者に対するメンタルヘルス教育に おいて，管理監督者をラインリスナーに位置づけてライ
ンリスナー教育を進めている。この場合，リスナーは単 に個人や職場の問題を把握するだけでなく，問題解決の ための具体的な助言，支援，指導等の迅速な行動も担っ ている，森崎はリスナー教育を担当するトレーナー養成 も図っているが，トレーナー教育の中には「パーソナリ ティ理論」「精神分析理論」等も含まれている。また， 実際のラインリスナーの教育においては，自我分析・交 流分析も取り入れられている.

森崎のリスナー教育は, ほぼ管理監督者教育に一致し, 職場に潜む組織や個人の問題に早期に対応していくこと がリスナーに対して期待されているという意味において は, 一次予防だけでなく, 二次予防の一部を含んだ㗢き かけのように思われる.

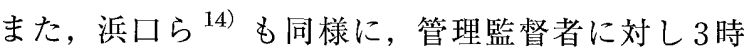
間 $\times 15$ 回のリスナー教育を行い, JMI 健康調查票を用 いて教育前後で受講者の変化を検討している. 結果にお ける統計学的説明が十分ではないが，職場健康度の検討 では，教育前から健康度が高かった教育群が，教育後も 対照群と同程度の増加を認めたことから，教育群により 強い健康増進反応があった可能性を示唆している.また， 精神健康度の比較では, 教育群が対照群よりも増加率が 高かったとしている.さらに，リスナー活動が他の従業 員に及ぼす影響について，初期に健康度の低い集団ほど 健康増進の反応が強い可能性を指摘している。

\section{III. リスナー教育の評価}

現状では，傾聴法やリスナー教育に関する研究論文は

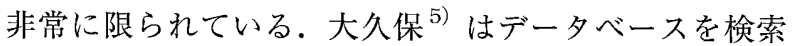
した結果を既に報告しているが，国内外を問わず，産業 医学領域における研究論文は非常に乏しい.

これには幾つかの理由が考えられる.職場のメンタル ヘルスに関する関心は高まってはきたものの，これまで は個別の対応や啓蒙が中心であったと考えられる．全国 的な規模で労働省作業関連疾患の予防に関する研究が行 われたのはつい最近のことである. その成果を基に，今 後は共通の測定法を用いた研究が行われるものと期待さ れる.

また，別の理由として，研修の効果を直接的に簡便に 測定する尺度がなかったことも，影響を及ぼしていた可 能性がある．前述の研究でも，一部ではりスナー教育の 効果が検討されているが，その場合に用いられているの は精神・心理状態を測定する一般的な心理テストや研究 者自身が作成した独自のテストであった，うつ，不安な どを測定する心理テストはPCA を直接的に測定したも のではない．また，独自作成のテストには，標準化され ていないという問題があった。

三島ら ${ }^{10)}$ は，傾聴的態度を測定する必要性を指摘し， その際によりどころとする，リスナー教育の効果を評価 
するためのモデルを提案している.効果評価のためには, まず，研修参加者の態度がPCAの方向へと変化してい ることを確認する必要があり，その上で，ストレス反応 などの変化を検討する必要があるとしている，このよう な目的で Mishima ら ${ }^{15)}$ は, 積極的傾聴態度評価尺度を 開発しているが, 現在, この尺度を用いた研究が進めら れている.

ここまでレビューしてきたことを要約すれば, 現状は, 傾聴法やリスナー教育による効果を示唆する研究はある ものの, 十分な科学的な根拠を持ってその効果が確認さ れたとは言い難い段階にあるということになる.しかも， 実際にその評価を積極的に研究している研究者の数も多 くはない，そこで今後の研究のために，検討すべき課題 をここで整理しておきたい。

研究すべきテーマは大別して二つある，第一は教育に 伴う直接効果の確認である.これは，教育や研修に参加 した者が本当にPCAの態度を獲得したか否かを客観的 に確認する研究である。研修参加者がPCAの態度を獲 得していなければ，全体への波及効果は期待できない. 第二に重要なテーマは, リスナー教育に参加した者が属 する集団や企業において, 勤労者全体のストレス対処能 力の改善や健康増進効果を確認することである.リスナ 一教育の本来の目的は, このテーマに関わることになる.

第一の研究では, 傾聴能力や PCAを評価する方法を 開発し，それを用いて教育前後で測定することが必要に なる。この研究は前述のように既に一部では行われてい る.この視点は研修指導者が教育, 研修の評価の一環と して組み达むことが可能であり，研修対象の事業所や自 治体の協力は比較的得られやすい. 仮にこの段階で十分 な効果が確認できない場合には, 教育研修方法の改善が 必要になってくる。

一方，本来の目的である集団全体の効果評価について は，その実施に当たって解決すべき様々な問題が残され ている, 例えば, 研究対象の設定, 研究デザイン, 教育 の効率化等の問題が考えられる.これらの点について詳 細に検討するのは, このレビューが扱う範囲を超えるの で，以下では重要な点を中心に簡単に整理したい。

研究対象としては, 事業所や自治体などの協力を得て 研究を進めることになるが, その際に, 研修参加者以外 の勤労者の健康情報にアクセスすることは，外部から訪 れた研修指導者には不可能な場合が多い。これを可能に するには, 当該事業所の人事労務管理者や健康管理ス夕 ッフと密接な協力関係を築き, リスナー教育の研究の意 義が理解されるように働きかける必要がある。また，研 究デザインの問題では, 種々のバイアスを効率よくコン トロールするには，対象集団をブロックとして，その中 で教育群と対照群を設定することが望ましいが，これを 実施に移すことは困難な場合が多い．何故なら，多くの
事業所では一般的に，対象となる集団全体に対して研修 を行扔うとするからである。ささらに，リスナー教育を依 頼する事業所は元々メンタルヘルスヘの関心が高い集団 と考えられるので, 対照群を異なる事業所に求める場合 には，交絡因子をコントロールするためにより多くの情 報を集める必要がでてくる，その上，検出力を高めるた めに対象集団の数を大きくしようとすれば，多くの管理 監督者に対してリスナー教育を行う必要が生じるが，こ れを短い期間で行おうとすれば，研修の効率化も大きな 課題となる.

このような問題を解決するための一つの方法として, 事業所の産業医や産業看護職自身が教育, 研修を担当す ることが対策として考えられる。しかし，現状ではリス ナー教育の指導を行うことが出来るスタッフは非常に少 ないであろう．従って，これを行うには，傾聴法の指導 方法を標準化し，職場において研修指導が行える指導者 を養成する研修を，産業保健スタッフに対して行う必要 性が生じてくる.

いずれにしても, 今後リスナー教育の研究を進めて行 くには，現実的な要請として，研究者や指導者が事業所 や自治体との間で協力関係を維持することが重要であ る. その為には, 教育, 研修が事業所や自治体から見て もメリットがあると感じられるものでなくてはならな い.そこで重要になるのが, 研修参加者の研修に対する 満足度ではないかと考えられる。その意味でも，科学的 評価とともに, 指導方法の研究そのものも重要なテーマ となるべきであろう.

\section{N. 終わりに}

産業医学において傾聴法についての知識が広まってき たのは間違いない.また，一般の雑誌で取り上げられ

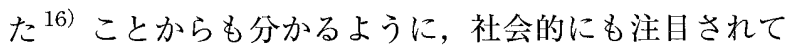
いるのも明らかである。しかし，傾聴法に関する学術的 な研究は非常に乏しいのが現状であり,これに関しては, 前述した通りである。ここではその繰り返しは避け，最 後に,メンタルヘルスとは別の視点から傾聴の可能性を 考えたい.

Rogersの最初の意図にもあるように，傾聴には部下 の育成という意味合いも含まれている，宮城の研究にお いても，リスナー教育の目的の中にそのような意味が含 まれている，部下の育成に関連して，米国では職場にお けるリーダーシップとして, Situational Leadership ${ }^{17)}$ という考え方が注目されている。これに基づけば，リー ダーは部下の能力やコミットメントに応じて, リーダー シップ・スタイルを変える必要があると考えられてい る.この中でリーダーがとる行動には 2 種類有り，一つ は指示的行動 (directive behavior) であり，もう一つ が支持的行動（supportive behavior）である.そして， 
傾聴は支持的行動の中の重要な要素として考えられてい る.このことは，職場において仕事を進めていく上でも 傾聴は重要な役割を担っているということを意味してい る.

これまで，ややもすれば，傾聴法は職場のメンタルへ ルスに関わる活動としてのみ捉えられ，特殊なものとし て考えられてきたきらいがある。しかし，今後の雇用形 態や職場環境の変化を考えるとき，管理監督者が部下の 能力を伸ばし, 仕事を円滑に効率よく進めていく上でも， 傾聴の重要性を認識する必要があるのではないかと考え られる。

\section{文献}

1）ロージァズ CR. ロージァズ全集（全 22 巻)。東京：岩 崎学術出版, 1966-1972.

2) Rogers CR. On Becoming a Person. Boston: Houghton Mifflin, 1961.

3）ロージァズ C R．第 3 部積極的な聴き方 (Active Listening)，ロージァズ全集第 11 巻 カウンセリングの立場. 東 京：岩崎学術出版, 1967: 307-332.

4）中央労㗢災害防止協会編. 心理相談員養成研修テキスト. 三秀舎, 1989: 236-245.

5）大久保利晃. 平成 11 年度労働省労働基準局認定要件設定 等のための調査研究 職域に扔ける積極的傾聴法の現状と 課題に関する文献的研究.

6）池見 陽，久保田進出，野田悦子㴗か，産業メンタル・ヘ ルスに抢けるパースン・センタード・アプローチの研究と 実践. 産業医学 1992；34: 18-29.

7) Hurrel JJ, McLaney MA. Exposure to job stress-A new psychometric instrument. Scand J Work Environ Health 1988; 14 (suppl 1): 27-28.

8) Kubota S, Mishima N, Ikemi A, et al. A research in the effects of active listening on corporate mental health training. J Occup Health 1997; 39: 274-279.

9）久保田進也, 三島德雄, 池見陽ほか. 管理監督者に対する 積極的傾聴法の有効性の検討．産業ストレス研究 1998; 6: 93-98.

10）三島德雄，久保田進也. 積極的傾聴法による職場のストレ スマネジメント．産業ストレス研究 2000; 7: 89-94.

11）久保田進也, 三島徳雄, 永田頌史ほか. 積極的傾聴法を中 心としたメンタルヘルス教育の方法に関する一考察－発見 的体験学習法の試み. 産業医学ジャーナル 2001；24: 24-31.

12）宮城まり子. 中間管理者へのカウンセリング教育の意義と その効果一 T社の管理教育における一例一. 産業カウンセ リング研究 1997; 1: 50-59.

13）森崎美奈子。労務管理の視点で展開する職場メンタルヘル ス教育一リスナー教育と組織育成一，産業ストレス研究 1998; 6: 99-105.

14）浜口伝博, 井上正岩, 大久保浩司ほか. 介入疫学手法によ る職場健康度に関する考察．産業医学ジャーナル 1994; 17: $50-56$.

15) Mishima N, Kubota N, Nagata $S$. The development of a questionnaire to assess the attitude of active listening. $\mathrm{J}$ Occup Health 2000; 42: 111-118.

16）堀田浩一. 聞き上手しか出世できない. AERA 2000; 13 (50): 29-32 (平成 12 年 11 月 27 日号).

17) Blanchard K, Carlos JP, Randolph A. The 3 Keys to Empowerment: Release the power within people for astonishing results. San Francisco: Berrett-Koehler, 1999.

\title{
Listener Education
}

\author{
Norio Mishima $^{1}$ and Shinya Kubota ${ }^{2}$ \\ ${ }^{1}$ Department of Mental Health, Institute of Industrial Ecological Sciences, \\ ${ }^{2}$ Occupational Health Training Center, University of Occupational and Environmental Health (UOEH)
}

\begin{abstract}
Listener education has usually been conducted as primary prevention in occupational medicine. We report on the present state of listener education in which the training focuses on active listening (AL). AL means the way of listening to a person in the person-centered attitude (PCA) that is based on Rogers' three conditions, i.e. empathy, unconditional positive regard, and congruence. Although the need of this kind of training has been widely described, there is a paucity of academic literature on this subject. This review deals with listener education by dividing it into two types; one is listener education in a narrow sense that consistently depends on the three conditions, and the other is listener education in a broad sense
\end{abstract}

that combines other methods that have different orientations from Rogers' theory. As an example of the former, Ikemi et al. reported the importance of the PCA, and studies conducted by Kubota et al., Mishima et al., and Miyagi dealt with the actual training. As an example of the latter, Morisaki and Hamaguchi et al. illustrated their training including other methods such as transactional analysis in their studies. Finally, we point out not only that future research needs to focus on the assessment of listener education, but also that AL needs to be understood from the standpoint of developing workers' competency. (San Ei Shi 2001; 43: 27-31) 